Available online at http://journal.unublitar.ac.id/jppnu

\title{
SOSIALISASI PENYIMPANAN PAKAN UNTUK MENINGKATKAN PENGETAHUAN PETERNAK SULTHON FARM
}

\author{
Lestariningsih $^{1}$, Rosidi Azis ${ }^{2}$ \\ ${ }^{1,2}$ Universitas Nahdlatul Ulama Blitar, Indonesia \\ E-mail: ${ }^{1}$ tariunu@gmail.com
}

\begin{abstract}
Abstrak: Mitra dalam pengabdian ini adalah Sulthon farm yang merupakan peternak mandiri ayam pedaging yang terletak di Dusun Centong, Kecamatan Kanigoro, Desa Sawentar Kabupaten Blitar. Kegiatan pengabdian ini bertujuan untuk meningkatkan pengetahuan mitra dalam penyimpanan pakan ayam pedaging. Mitra mengalami kesulitan dalam melakukan penympanan pakan. Berdasarkan pengalaman yang telah dilaksanakan oleh mitra diketahui bahwa pakan mitra sering sekali berjamur sehingga tidak dapat bertahan lama. Hal ini dapat berdampak kepada produktivitas dari ayam pedaging mitra. Metode yang digunakan adalah survey, wawancara dan dilanjutkan dengan sosialisasi penyimpanan pakan ayam pedaging. Berdasarkan hasil pre test dan post test diketahui bahwa sosialisasi penyimpanan pakan ayam pedaging kepada mitra dapat meningkatkan tingkat pengetahuan mitra sebesar $40 \%$. Hal ini perlu ditindaklanjuti dengan praktek secara langsung dalam penyimpanan pakan ayam pedaging di peternakan mitra.
\end{abstract}

Kata Kunci: broiler, unggas dan fifo.

\section{PENDAHULUAN}

Blitar merupakan salah satu daerah berpotensi dalam pengembangan peternakan ayam pedaging. Selama itu Blitar terkenal sebagai salah satu penyuplai terbesar unggas di Indonesia. Berdasarkan update data BPS pada Januari 2018 diketahui bahwa populasi ayam pedaging di Blitar sebesar 43.171 ekor (Badan Pusat Statistik Jawa Timur, 2018). Namun pengembangan ayam pedaging di Blitar masih didominasi peternak berbasis kemitraan. Namun demikian ada beberapa peternak mandiri yang masih bertahan salah satunya adalah Sulthon Farm. Peternak mandiri ayam pedaging ini berdiri sejak tahun 2013. Peternak mandiri mempunyai banyak sekali permasalahan diantaranya adalah biaya pakan yang tinggi mencapai $70 \%$ dari keseluruhan biaya operasional (Jamilah, 2016). Hal ini menuntut peternak untuk lebih memperhatikan aspek pakan. Salah satu hal yang berperan penting dalam pakana dalah penyimpanan pakan. Menurut teori penyimpanan pakan mengunakan metode FIFO (First In First Out) yang maksudnya bahwa pakan yang pertama datang maka pakan tersebut harus digunakan terlebih dahulu. Hal ini mengingat pakan ternak mempunyai daya simpan 
Available online at http://journal.unublitar.ac.id/jppnu

yang cukup terbatas. Jika tidak segera digunakan maka kemungkinan besar akan terkontaminasi salah satunya adalah jamur.

Berdasarkan hasil wawancara kepada mitra diketahui bahwa pakan yang diguunakan mitra terkadang berjamur. Hal ini kemungkinan disebabkan penyimpanan yang kurang tepat. Pada peternakan mitra, pakan dalam penyiimpanan tidak menggunakan alas. Oleh karena itu pakan langsung menyentuh tanah yang lembab dan hal ini menjadi peluang kontaminasi jamur. Oleh karena itu, diperlukan sosialisasi cara penyimpanan pakan ayam pedaging kepada mitra untuk meningkatkan pengetahuan mitra dalam menyimpan pakan ayam pedaging dipeternakannya.

\section{METODE}

Kegiatan sosialisasi ini dilaksanakan pada bulan Mei 2019 di Kampus 1 UNU Blitar yang terletak di Jalan Masjid No. 22 Kota Blitar. Kegiatan sosialisasi ini dihadiri 10 orang yang terdiri dari pengabdi ( 2 orang) dan pihak mitra (8 orang). Alat dan Bahan yang diperlukan adalah LCD, laptop dan materi kegiatan penyimpanan pakan ayam pedaging. Metode yang digunakan adalah survei, wawancara dan dilanjutkan dengan sosialisasi penyimpanan pakan ayam pedaging. Pengukuran tingkat pengetahuan mitra dengan memberikan pre test dan post test. Pelaksanaan program terdiri dari 3 tahap yaitu

1. Tahap pra kegiatan (survey, wawancara dan koordinasi dengan mitra).

2. Tahap pelaksanaan kegiatan yang terdiri dari kegiatan sosialisasi penyimpanan pakan ayam pedaging.

3. Tahap pasca kegiatan yaitu melaksanakan evaluasi dengan memberikaan angket pre test dan pos test kemudian dilakukan analisis untuk menentukan kenaikan tingkat pengetahuan mitra.

Data yang telah diperoleh selanjutnya diolah dengan menghunakan excel kemudian dibuat grafik untuk mengetahui tingkat engetahuan mitra. Kemudian data dianalisis secara deskriptif. 
Available online at http://journal.unublitar.ac.id/jppnu

\section{HASIL DAN PEMBAHASAN}

Mitra dalam kegiatan ini adalah Sulthon Farm yang merupakan peternak mandiri ayam pedaging. Mitra menjalankan peternakannya sejak tahun 2013 dengan populasi 200 ekor. Peternak mandiri harus memiliki modal sendiri untuk pembelian DOC dan harganya pun sesuai dengan harga yang berlaku. Selain itu, untuk pembiayaan pembuatan kandang, perawatan kandang, pembersihan kandang, pakan ternak, obat dan vitamin dilakukan dengan modal sendiri. Setelah panen, maka hasil panen akan dipasarkan sendiri dan mengikuti harga yang berlaku dipasaran namun punya kebebasan dalam menggunakan brand produk perusahaan manapun. Disamping itu modalnya relative lebih tinggi dan tidak ada pendampingan atau bantuan teknnis dari perusahaan. Namun demikian, peternak mandiri bebebas untuk berinovasi sesuai dengan keinginannya (Amenuri, et al, 2006).

Kendala utama pada umumnya dipeternakan mandiri adalah mortalitas yang tinggi dan konversi pakan yang tinggi (Fadilah, 2006). Salah satu penyebabnya adalah tidak ada pendmapingan dari pihak lain. Disisi lain, dalam usaha peternakan diperlukan perhatian pada 3 aspek unsur produksi yaitu managemen (pengelolaan usaha), breeding (pembibitan) dan feeding (pakan ternak) (Rasyaf, 2003). Meskipun tidak bisa dipungkiri bahwa pakan ternak memegang biaya operasional yang tertinggi (70\%) sehingga perlu mendapat perhatian (Elis, 2014).

Mitra mengalami kesulitan dalam managemen pakan salah satunya adalah penyimpanan pakan sehingga banyak ditemui pakan mitra yang mengumpal dan berjamur. Oleh karena ini dalam program pengabdian ini dilakukan sosialisasi penyimpanan pakan ayam pedaging untuk meningkatkan pengetahuan mitra. Kegiatan tersebut dilaksanakan pada bulan Mei 2019 di Kampus 1 UNU Blitar.

Kegiatan sosialisasi dimulai dengan pemberian test awal. Hal ini untuk mengukur tingkat pengetahuan mitra sebelum sosialisasi. Setelah itu dilanjutkan dengan sosialisasi penyimpanan pakan ayam pedaging. Penyimpanan pakan mengacu kepada prinsip Fisrt In First Out (FIFO) yaitu pakan yang datang terlebih dahulu maka akan digunakan lebih awal dibandingkan dengan pakan yang dating pada waktu akhir. Selain itu, dalam kegiatan sosialisasi ini menjelaskan terkait dengan bahan - bahan yang dapat digunakan sebagai alas pakan ternak serta cara penggunaannya dalam penyimpanan pakan. Setelah 
Available online at http://journal.unublitar.ac.id/jppnu

selesai kegiatan maka dilaksanakan post test dengan soal yang sama pada saat pre test. Berdasarkan hasil analisa diketahui bahwa sosialisasi pemberian pakan dapat meningkatkan pengetahuan mitra sebesar $40 \%$. Hasil pre test menunjukkan nilai $30 \%$ sedangkan hasil post test menunjukkan hasil 70\% (Gambar 1.).

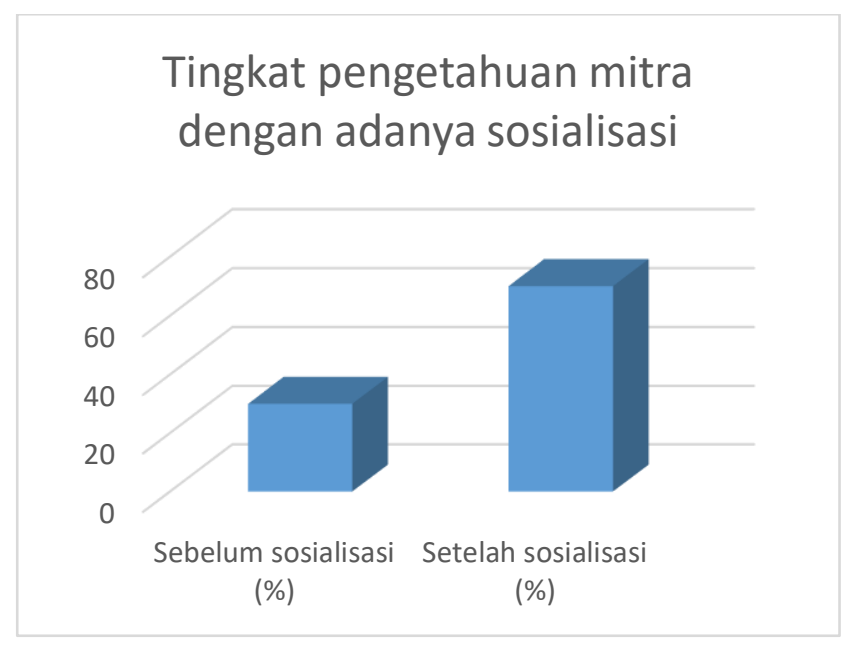

Gambar 1. Peningkatan pengetahuan mitra dengan adanya sosialisasi

\section{KESIMPULAN}

Sosialisasi penyimpanan pakan ayam pedaging dapat meningkatkan $40 \%$ tingkat pengetahuan mitra (Sulthon Farm).

\section{SARAN}

Program sosialisasi penyimpanan pakan ayam pedaging ini dapat dilanjutkan dengan praktek secara langsung terkait dengan cara penyimpanan pakan ayam pedaging dengan sistem FIFO.

\section{DAFTAR RUJUKAN}

Amenuri, F.I., S.T. Soekarto dan Suryahadi. 2006. Perbandingan system usaha mandiri dan plasma pada pembesaran ayam ras pedaging terhadap tingkat pendapatan (Studi kasus di Parung). Jurnal MPI Vo. 1. No. 2. 
Available online at http://journal.unublitar.ac.id/jppnu

Badan Pusat Statistik Jawa Timur. 2018. Populasi Ternak Menurut Kota. https://jatim.bps.go.id/statictable/2018/01/31/787/populasi-ternak-unggasmenurut-kabupaten-kota-di-provinsi-jawa-timur-2013.html. diakses $\operatorname{tgl} 1$ September 2018.

Elis. 2014. Analisis faktor pendorong peternak ayam broiler melakukan kemitraan dikecamatan Marusu Kabupaten Maros. Fakultas Peternakan. Universitas Hasanuddin. Makasar.

Fadilah, R. 2006. Panduan mengelolan peternakan ayam ayam pedaging. Agromedia Pustaka. Jakarta.

Jamilah. 2016. Pola usaha peternakan ayam ras pedaging di Aceh. Jurnal Agrivo Vol. 1 No. 2.

Rasyaf, M. 2003. Memasarkan hasil peternakan. Penebar Swadaya. Jakarta. 